\title{
Evaluation of the Blackboard Learn Learning Management System for Full Online Courses in Western Branch Colleges of Qassim University
}

\author{
https://doi.org/10.3991/ijet.v15i15.14199 \\ Fahad Alturise \\ Qassim University, Al-Qassim Province, Saudi Arabia \\ Falturisedqu.edu.sa
}

\begin{abstract}
With recent advances in information technology, higher education institutions began to transit from existing, traditional teaching methods to the alternative Blackboard Learn Learning Management System (LMS) from Blackboard Inc. In this context, the western branch colleges of Qassim University in the Kingdom of Saudi Arabia started using the Blackboard Learn LMS for e-learning for the first time in the academic year of 2016. At the first stage of the project, the Deanship of e-learning launched ecourses for full Islamic 101 and full Islamic 102 online in the university and trained all faculty members and students in the new e-course full level programs. Based on the newly developed, full online courses, a survey was conducted in the college of the western branch of Qassim University regarding difficulties and limitations, and the faculty members and student's satisfaction regarding Blackboard Learn using full online courses on campus. A detailed evaluation of the survey concludes that the implementation of e-courses is a significant step forwards, but that it required significant work to gain necessary improvement.
\end{abstract}

Keywords-Blackboard Learn, Qassim University, e-learning, Learning

Management System.

\section{Introduction}

The global educational trend during the past decade is for face-to-face teaching, learning and communication to be replaced with e-learning (electronic learning). Elearning features the use of an interface and website in which both faculty members and students can learn and communicate from anywhere in the world, with the use of a personal computer, laptop or even a smartphone. The author in [1] uses a combination of e-learning and online communication as a blended learning tool. The primary objective of this tool is to provide a proper interface to students and teachers for better learning [2]. As mentioned, early e-learning has helped in reducing the distance between students and teachers through the use of an interface website on the internet. Before the introduction and advent of e-learning, it was impossible for both 
faculty members and students to communicate and learn outside the physical educational institution [3].

Nowadays, educational institutions in developed countries are shifting from conventional means of teaching and tutoring to a newer way known as e-learning via different apps. E-learning is achieved by utilizing a Learning Management System (LMS). A variety of initiatives, such as investments and awareness, are underway to tempt faculty members to use it for their educational purposes. LMS comprises of assignments, course books and other study materials for students to benefit from[29].

It has been observed globally that the development of technology is exponentially growing, and with this, communication and e-learning are also growing day by day. Still, the University of Technology (under observation and study) is lagging behind in the field of e-learning. With the increase in the literacy rate all over the world, more students are getting enrolled in educational institutions which results in overpopulated classes and challenges for students to interact with their teachers, despite a significant investment in e-learning software such as Blackboard Learn. Internet services are available for students whenever they are on campus, but not everyone has the internet at home as well [4]. The use of Blackboard Learn still appears to be limited as students are only at university for a finite time period.

The idea to develop an online education system was proposed by two educational advisors, whose primary objective was an innovation in the educational system which would help both students and faculty members. This has presently helped educational institutions by delivering all educational and course information to anywhere in the world online. Another benefit is the provision of an interface where faculty and students can communicate anywhere, anytime [5]. The Blackboard Learn system is the easiest and most efficient means for students to get in touch with their teachers, with the added feature of a transparent and justified grading system. The authors in [6] have developed a model, namely UTAUT, for the identification of various factors responsible for lower adaptation of Blackboard Learn by the faculty. Results showed that Blackboard Learn could be a great tool for the improvement and innovation of the learning and education systems.

Several types of survey have been conducted based on the functional analysis of the Blackboard Learn user experience, faculty experience, and student opinion. A comparative study between different functions such as peer-to-peer communication, student-to-interface interaction, communication between faculty members and students etc. is being undertaken by the author in [7]. The authors in [8] studied different aspects related to communication and information technology. The study was conducted by 1 styear students of the University of Botswana. These students had not used any type of e-learning such as Blackboard Learn, computers, or the internet in their studies. Two hundred students from the second semester of the class of 2013/2014 involved in ENG 131 and ICT 121 were given a questionnaire. In the meantime, researchers performed a study relative to the observations of class, students and faculty members. A theoretical framework was formed by using the constructivist theory of learning. The results of interviews and studies revealed that the main issue that students faced in using Blackboard Learn was downloading content from and uploading to the website. Also, students had challenges understanding the website 
interface and taking tests and quizzes using Blackboard Learn. They were also unaware of other features provided by ICT tools. Research revealed that 1 st year students need to be given proper attention in providing them with knowledge about computer skills and then the Blackboard Learn interface, so that they can perform well in their future studies. The authors in [9] conducted an observational study regarding the probems interfacing with the Blackboard Learn website and e-learning in general at King Saud University. Hypothesis-based research was performed which concluded that Blackboard Learn was an easy tool to interface with, but in the end, this hypothesis turned out to be false. The study investigated various features of Blackboard Learn, such as navigation, interface, and other options. Researchers suggested that minimal training could help the faculty members and students use the Blackboard Learn software very easily. Researchers further suggested that the university should offer practice courses for English and Arabic which would help the students and faculty members to get used to the Blackboard Learn interface.

The authors in [10] conducted a survey in Bisha, KSA in which the achievements in e-learning by the faculty members were investigated, showing that the teaching methods have drastically improved with the introduction of e-learning. Forty students of various standards were selected at random for a specific study, with 20 students allocated to each of the experimental and control groups. Both groups analyzed the teaching methodology of teachers. The experimental group was taught using elearning such as Blackboard Learn, whereas the control group was taught with conventional teaching methods. After the completion of the course, students from both groups were given a test. The test results showed that the students who learnt through Blackboard Learn performed better when compared with the control group who were taught using conventional teaching methods.

There are various benefits of e-learning, but two of them are highly significant. One, teachers can easily predict who are the weaker students and can take feedback from them at the same time. Two, teachers can provide lectures and further assistance to students for enhanced learning. Nowadays, Blackboard Learn is used for online communication and learning and hence provides many study opportunities for researchers.

\section{$2 \quad$ Literature Review}

Michael Chasen and Matthew Pittinsky, who were educational advisors by profession, together formed Blackboard LLC in 1997. Blackboard LLC then partnered with IMS Global Learning and formed Blackboard Inc. IMS Global was a non-profit organization which was a part of the national Educause initiative program. The primary objective of Blackboard Learn was to provide an interface for both faculty members and students, along with college and university professors, for easy communication between them. Moreover, teachers would be able to upload course content and significant notes regarding courses where all the class students of could easily benefit from it. Blackboard Inc. then merged with a course management company named CourseInfo. CourseInfo, being a startup company located at Cornell 
University, together with Blackboard Inc. developed and launched online e-learning software. Subsequently, Blackboard Learn prevailed by acquiring MadDuck technologies, who were Richmond-based competitors. After almost a year, in January 2001, access solution for campus was bought by Blackboard Inc. from AT\&T. CEI special teams were also purchased by Blackboard Inc. from iCollege. Then, another educational competitor, namely Promethius, was bought by Blackboard Inc. from George Washington University. In 2003, Blackboard Inc. acquired some assets of transaction company SA cash. Then, in June 2004, after raising the considerable sum of $\$ 75$ million by offering initial stock, Blackboard Inc. went public. They then merged with another e-learning company called WebCT, and thus cover almost $80 \%$ of course management and online e-learning systems in the whole of North America. According to a study, Blackboard Inc. is used by more than 70 of the educational institutions in the States. Approximately 12 million people in 60 different countries use Blackboard Learn, according to a study from 2006. Blackboard Inc. offers courses and interfaces to about 2,200 educational institutions in 12 different languages containing 2,500+ publications and supplements from educational researchers and publishers. It is traded via NASDAQ and in 2005 its stock price approximately doubled. Revenue generation and trading were mostly generated from the renewal of licenses and that's why more investors are willing to invest in Blackboard Inc. today [11].

\section{Blackboard Portfolio of Products}

Blackboard Learn offers two products, namely Networked Transaction Environment (NTE) and Networked Learning Environment (NLE) [12, 13]. As evident from the name, NTE deals specifically with the transaction system, a kind of commerce suite. It further controls the transactions of $\mathrm{Bb}$ One and the Blackboard Community System. The essential function of NTE is to provide suitable software capable of handling worldwide commerce and transactions by Blackboard Learn. Furthermore, it gives access to faculty members, students and other members of the campus to create accounts. It also helps in tracking any transactions with a single card all over the world. Conversely, NLE provides services related to study, like course contents as a kind of academic suite. We can confidently say that Blackboard Learn can be called the heart of NLE as it provides many services related to study and courses [27].

\section{$4 \quad$ Blackboard System Utilization}

An overall overview of Blackboard Learn shows that Blackboard is not only a part of e-learning and the LMS, but it also provides an accurate and easy interface for communication between faculty members and students, with the extra features of discussion boards, emails and podcasts etc. Different kinds of users may get different benefits from Blackboard Learn. A user who is completely aware of the can use it more efficiently than someone with less e-learning knowledge about e-learning [14, 
15]. The use and efficiency of Blackboard Learn for students is dependent on teachers. If teachers use Blackboard Learn extensively and efficiently, students will follow them to use it to their fullest [16]. According to a survey, it was concluded that only 23 percent of faculty members are able to completely integrate courses with online e-learning. This is below average for the successful and efficient use of Blackboard Learn. There is also a strong need for awareness and tutorials need to be provided to both students and faculty members which address the advantages of elearning [17]. It's been concluded from analysis and research that Blackboard Learn is the perfect tool for students to gain enough knowledge easily and efficiently as it provides the useful advantage of an easy interface for communication, quizzes, exams, grading, and assignments. Currently around $70 \%$ of educational institutions are using Blackboard Learn [17].

\subsection{Use of blackboard learn by faculty's}

The role of the faculties, particularly of teachers, is key to student awareness of elearning. The authors in [18] concludes from his research and analysis that professors in universities rely on Blackboard Learn for optimum organization of their courses and better communication between students and teachers. The authors in [19] researched and concluded that some professors mention that Blackboard Learn is inflexible and students find it difficult to use efficiently. Possibly the limitations of Blackboard Learn are responsible for the inflexibility and lower adaptation by students [28].

\subsection{Use of blackboard learn by students}

The efficient and productive use of Blackboard Learn is dependent on several different factors, including the enthusiasm, dedication, and awareness of the user regarding the software. However, the authors in [20] highlight other problems such as financial factors and family social and moral support which can result in the limited use of Blackboard Learn. Some students also have jobs which limit their online activities; hence it becomes difficult for them to gain online knowledge using Blackboard Learn [21]. Employment and commitment to other social activities lead to poor student uptake of Blackboard Learn [22]. Aside from all these factors, students do need to learn and use Blackboard Learn software to gain better quality knowledge and education. Blackboard Learn further helps students to send online feedback to their teachers at which time they can resolve student issues. Students can also submit their queries via email. Some other student features of Blackboard Learn follow:

1. Discuss and write at the same time

2. Revision of any previous class from the teachers notes

3. Download soft copy of notes anytime from anywhere

4. Add personal comments to a discussion

5. Cut or paste data from or to any file in the Blackboard software

6. Edit any document and reorganize it accordingly 


\section{$5 \quad$ Full Online Course of Qassim University}

The electronics courses were developed after the better, encouraging experimental phase outcome in 2016. The initiatives for the development of e-learning were taken by the Deanship to expand e-learning to an extended form by offering psychology 101, Islamic 101 and 102 in online courses. The below steps were taken for the implementation.

The faculty members of different colleges such as "college of education" and "college of Sharia and Islamic studies" were contacted to nominate the content experts for the first proper startup of e-learning. The faculty members collectively nominated course experts for specific subjects. To review the production standards of course content, timetable, and interfaces a meeting was held between the course experts and external personnel involved in the initial implementation of e-learning. Some positives from the meetings were the establishment of a platform for communication between course experts and the external body for further decision making and content production for to avoid any issues.

The courses selected for e-learning were issued course content which was sent to the relevant authorities for confirmation and technical review. Course experts and the Dean reviewed the course outline. There were some changes required and there were sent to the production team for the changes to be made. The courses after the amendments were sent to authorities for launching in the second semester of 2016. Respective course guidelines were sent to the relevant teachers implemented ahead of time.

A seminar was arranged by the Deanship which addressed the students of different colleges of the university who had taken part in the previous experimental analysis. The Deanship provided the necessary guidelines and motivation to students to get registered in online courses. Seminars further provided the skills required to fully embrace e-learning. During the seminar the Deanship also communicated with the teachers who were most probably going to teach the online courses in the subsequent semester. They were asked to do a presentation in the seminar as an introductory session on the online courses to be taught the following semester. The presentation was given to both students and professors. Students participated in a training workshop designed to familiarize and explain the use of the online interface.

The Deanship further provided guidelines to professors regarding teaching skills for the courses. Also, they were provided with the necessary skills and guidelines on the online communication with students, the management of classes, the evaluation of assignments and quizzes, and other miscellaneous issues regarding e-learning. Administration prepared a task schedular list for teachers and the same was made available to students to follow up with a kind of a calendar for teaching online which showed the assignments, exams, and other relevant tasks to follow in the time ahead. According to the requirements of professors some changes were made to sort out the calendar. 
In the first two weeks of the semester, some challenges were faced by the Deanship and other authorities had not provided student data to other authorities, so proper teaching of online courses was started after the second week of the semester.

From the start of the project, there were issues, which were the main concern of the Deanship around distance education and e-learning. The issues related to online course teaching by the professors, with additional issues related to the student understanding of their participation in activities, content browsing, follow up center, dashboard, interaction, and communication and assessment center. The course was published by the respective course teachers and the students used the calendar and management system from then onwards. After that, a survey of the full program was conducted and reviewed by experts to check the credibility of e-learning. Details of the survey and the feedback from university faculty members and students are thoroughly investigated in the following sections.

\section{$6 \quad$ Survey Design Full Online Course Survey Design}

A questionnaire-based survey was conducted involving faculty members and students in the colleges of the western branch of Qassim University in the Kingdom of Saudi Arabia. This survey was based on the full online course of the Deanship which was launched in the first phase of the project to build and develop e-courses at the university. The first electronic content was designed and developed for Psychology 101, Islamic 101, and Islamic 102Note that the western branch colleges of Qassim University implemented a full online course for the first-time last semester with six full online topics from different disciplines. After completing the topic, a survey was given to students and faculty members to review their thoughts and the performance of the process.

The survey was prepared on web-based applications designed for data collection purposes such as Google Form. Without using any external software, the feedback was received and stored for detailed analysis. To present data analysis, in the form of charts and graphs, of the feedback from teachers and students the Google Form is integrated with Google Spreadsheets which not only provide graphs but also give a spreadsheet view of the collected feedback.

In the initial stage of the survey on full online courses after the Deanship seminars, symposium, training workshops, teacher guidance, and student training on e-learning, the survey was conducted to investigate faculty members and student feedback regarding the new full online e-course. The survey was designed so that all participating faculty members were asked 37 questions and all students were asked of 32 questions. The 12 most significant questions for the faculty members, and 11 from the students are considered here for investigation.

There were 23 faculty members, including 15 males and eight females, participating in the survey along with 639 students comprising 368 male and 271 females. It is worth mentioning that an email containing the survey link was sent via the university email address to all students and faculty members for participation. Note the overall questionnaire was divided into small sub-sections based on 
demographic data such as age, gender, and academic position. Moreover, the questionnaire was composed of two types of questions, one responsd with yes or no, and two with a detailed point of view of strongly disagree, disagree, neutral, agree and strongly agree. A comprehensive overview of the feedback received from the faculty members and students is listed in the results and discussion section below.

\section{$7 \quad$ Results and Analysis}

Since the surveys were performed separately with faculty members and students on full online courses, the results achieved from both groups were investigated individually. The main goal of the survey and information in this paper is to investigate the challenges which faculty members and students face in the new elearning LMS system, and identifies the limitations of the system so the necessary improvements can be made in the up-coming version of the system.

\subsection{Faculty members feedback}

The faculty questionnaire was composed of two sections. The first section mainly focused on the training and handling of the electronic course in such a way that all students could become capable enough of self-learning to present practical course work activities included in the course description. Details of the first section of the questions along with the results are listed in Table 1 below. Based on the teacher point of view in the feedback, it is evident that out of the 23 faculty members questioned, only $17(73.9 \%)$ of them received training and can handle the full e-course. Moreover, only $21(91.3 \%)$ of the faculty members knew how to manage the students' selflearning process analysis reveals that e-courses make it easy for faculty members to thoroughly guide students regarding the practical activities of the course, however despite providing all course description, students fail to present practical activities to their respective course professors.

Table 1. Faculty questionnaire and feedback regarding training and handling the e-course

\begin{tabular}{|l|c|c|c|c|}
\hline \multicolumn{1}{|c|}{ Questions } & \multicolumn{2}{c|}{ Yes } & \multicolumn{2}{c|}{ No } \\
\cline { 2 - 5 } & $\boldsymbol{T}$ & $\mathbf{\%}$ & $\boldsymbol{F}$ & $\mathbf{\%}$ \\
\hline I received training in electronic self-learning methods & 17 & 73.9 & 6 & 26.08 \\
\hline I received training on how to handle full e-courses & 17 & 73.9 & 6 & 26.08 \\
\hline I have enough knowledge of how to manage the self-learning process for students & 21 & 91.3 & 2 & 8.69 \\
\hline $\begin{array}{l}\text { The electronic course enables the course professor to provide advice to students so } \\
\text { that they can carry out practical activities related to the course }\end{array}$ & 16 & 69.56 & 7 & 30.43 \\
\hline $\begin{array}{l}\text { The electronic course enables the student to present practical activities to the } \\
\text { course professor }\end{array}$ & 6 & 26.08 & 17 & 73.9 \\
\hline The course electronic content included all the elements in the course description & 16 & 69.56 & 7 & 30.43 \\
\hline
\end{tabular}

The second section of faculty questionnaire relates to the e-content of the course objective, the course content characterized by scientific accuracy, language integrity and clarity, practical skills, and ease of browsing. From Fig 1, it is evident that 
$21.73 \%$ strongly disagreed and $13.04 \%$ disagreed that the developed e-content of the course will facilitate achieving the objective of the course. However, 39.13\% agreed and $17.39 \%$ strongly agreed the course objective will be achieved while the remaining of $8.69 \%$ were neutral. It is can be seen that only $34.77 \%$ of the faculty members think that the objectives of the course may not be reached.

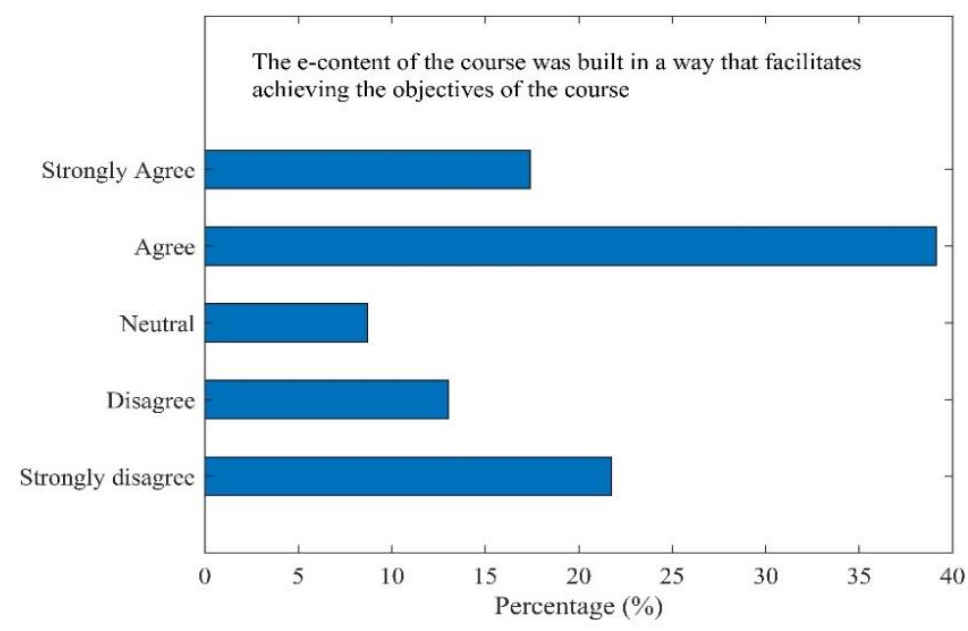

Fig. 1. Faculty feedback about achieving the course objective

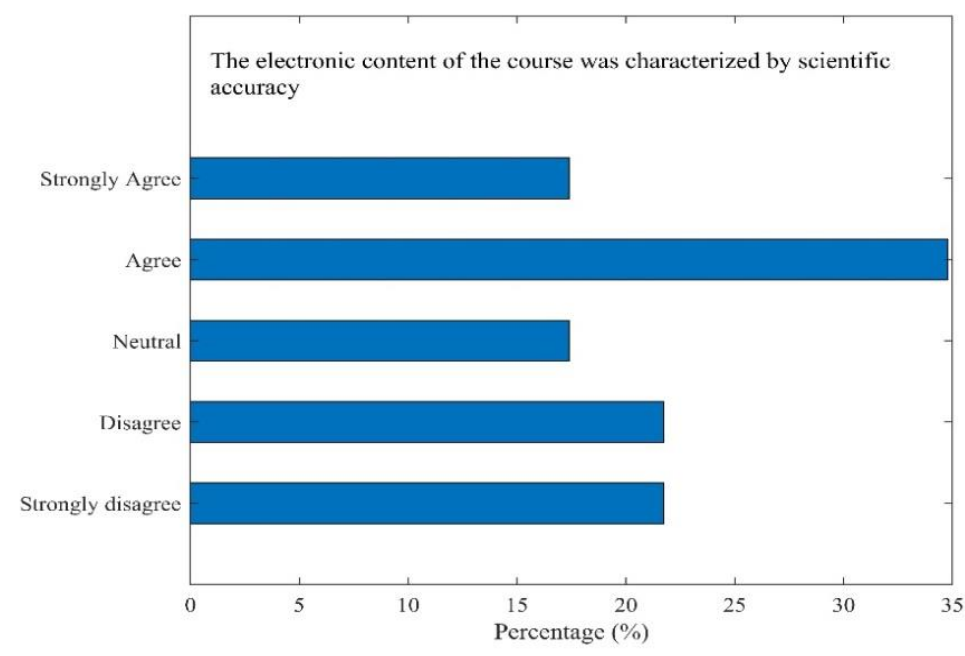

Fig. 2. Feedback about course characterization with scientific accuracy

From Fig 2, analysis reveals that $8.69 \%$ strongly disagreed and $21.73 \%$ disagreed that the e-content of the course is characterized with scientific accuracy. However, $34.78 \%$ agreed and $17.39 \%$ strongly agreed regarding e-course content characterization whereas the remaining $17.39 \%$ faculty members were neutral. It can 
be seen that $52.17 \%$ of the faculty members agree that the e-course content is characterized with scientific accuracy. Whereas, Fig 3 shows that apart from $26.08 \%$, all other faculty members agreed that the e-content of the course is characterized by language integrity and clarity.

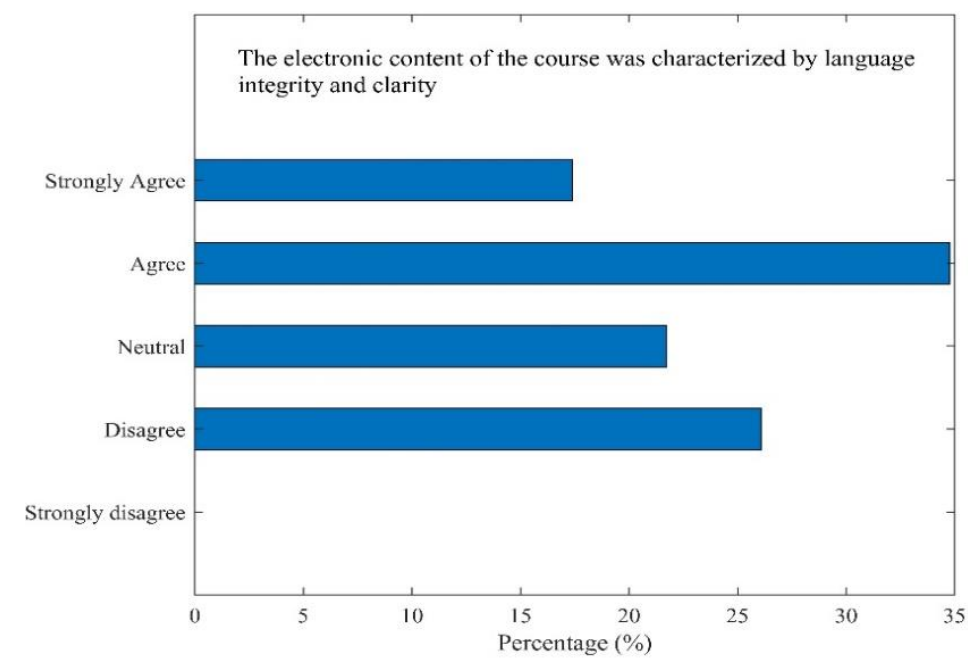

Fig. 3. Feedback about course characterization by language integrity and clarity

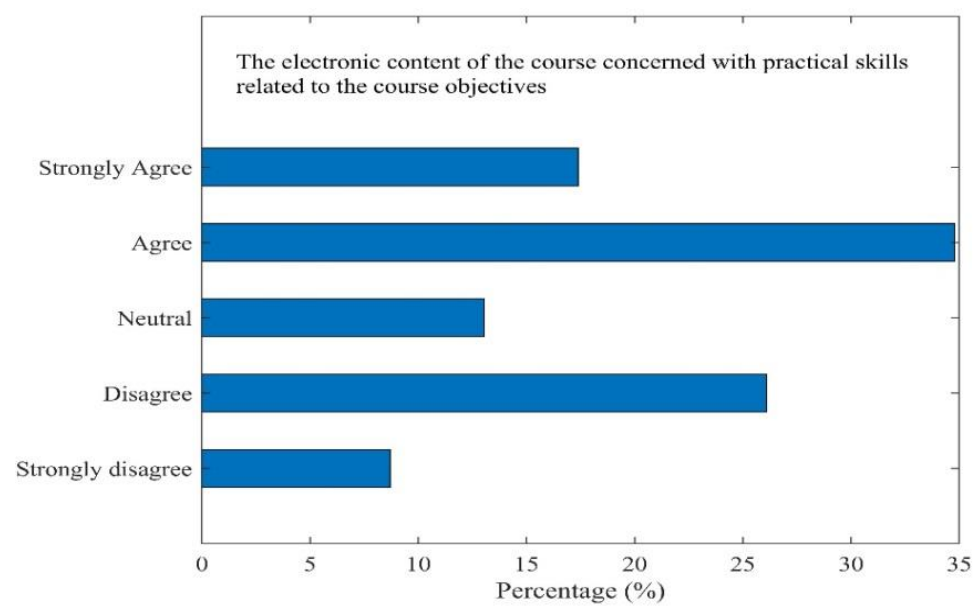

Fig. 4. Response regarding practical skills about course objective

Fig 4 analysis shows that $8.69 \%$ strongly disagree and $26.08 \%$ disagreed that the practical skills related to the course achieved the course objective. However, $34.78 \%$ agreed and $17.39 \%$ strongly agreed whereas the remaining $13.04 \%$ faculty members were neutral. It can be seen that $34.77 \%$ of the faculty members disagreed that the course concerned with practical skills achieved the course objective. 
Fig 5 shows that a total of $43.46 \%$ disagreed that the e-course content can be easily browsed, whereas $34.78 \%$ agreed and $17.39 \%$ strongly agreed and $13.04 \%$ faculty members were neutral.

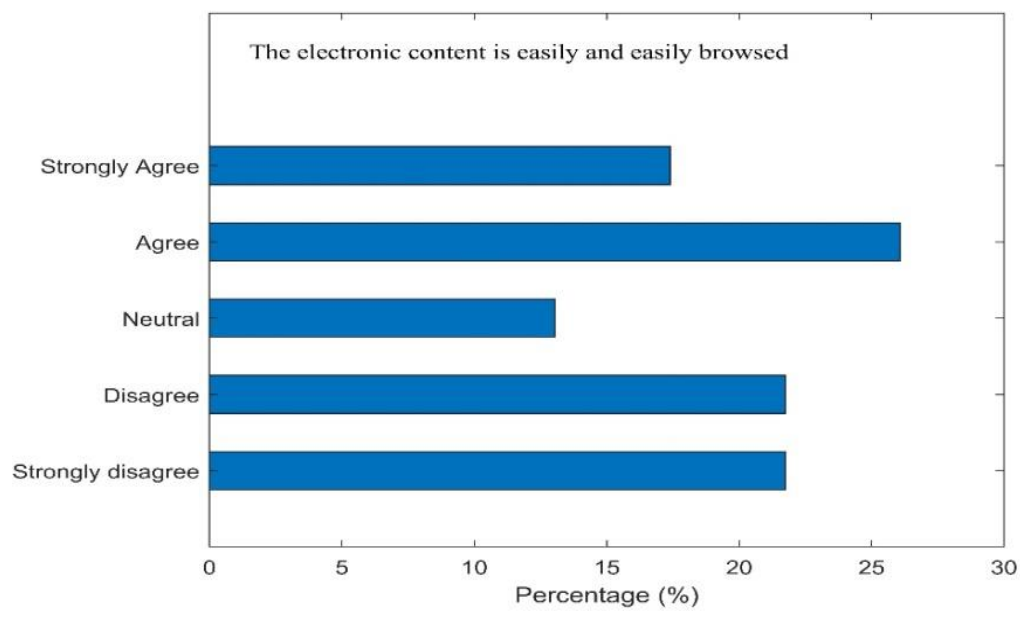

Fig. 5. Faculty feedback on browsing course content

Table 2. Quantitative evaluation of the faculty members feedbacks

\begin{tabular}{|l|c|c|c|c|c|}
\hline \multicolumn{1}{|c|}{ Questions } & \multicolumn{4}{c|}{ Faculty decision (\%) } \\
\cline { 2 - 6 } & $\begin{array}{l}\text { Strongly } \\
\text { disagree }\end{array}$ & Disagree & Neutral & Agree & $\begin{array}{c}\text { Strongly } \\
\text { agree }\end{array}$ \\
\hline $\begin{array}{l}\text { The e-content of the course was built in a way } \\
\text { that facilitates achieving the objectives of the } \\
\text { course }\end{array}$ & 21.73 & 13.04 & 8.69 & 39.13 & 17.39 \\
\hline $\begin{array}{l}\text { The electronic content of the course was } \\
\text { characterized by scientific accuracy }\end{array}$ & 8.69 & 21.73 & 17.39 & 34.78 & 17.39 \\
\hline $\begin{array}{l}\text { The electronic content of the course was } \\
\text { characterized by language integrity and clarity }\end{array}$ & 0 & 26.08 & 21.73 & 34.78 & 17.39 \\
\hline $\begin{array}{l}\text { The presentation of electronic content was } \\
\text { appropriate for the students' level }\end{array}$ & 8.69 & 34.78 & 17.39 & 21.73 & 17.39 \\
\hline $\begin{array}{l}\text { The electronic content of the course concerned } \\
\text { with practical skills related to the course } \\
\text { objectives }\end{array}$ & 8.69 & 26.08 & 13.04 & 34.78 & 17.39 \\
\hline $\begin{array}{l}\text { The electronic content is easily and easily } \\
\text { browsed }\end{array}$ & 21.73 & 21.73 & 13.04 & 26.08 & 17.39 \\
\hline
\end{tabular}

A comprehensive and quantitate analysis of the faculty questionnaire are listed in Table 2. Analysis concluded that the majority of the faculty members agreed that the full online e-course offered by the western branch colleges of Qassim University, achieved the course objectives with appropriate e-content which are characterized with scientific accuracy, language integrity, and practical skill that can be easily browsed. 


\subsection{Students feedback}

The student questionnaire was also composed of two sections. The first section mainly focused on the system handling, usage through computer/smart devices, teacher experience for problem solving, technical support, and response of technical support of the Blackboard Learn system. A detailed investigation of the students feedback along with the results are listed in Table 3. Based on the student's point of view in the feedback, it can be seen that out of 639 students, only 329 received training on how to handle the full e-course. Moreover, despite having no training, the highest ratio of students can deal with the Blackboard Learn system, not only through a computer but also with smart devices. However, feedback revealed that the same ratio of students are unaware of solving technical issues and the technical support team did not reply promptly. But it is good that e-course teachers have enough experience and can help students in cases when they need assistance.

The second section of student questionnaire relates to the course guidelines, course browsing within the e-course, teamwork skills, and student satisfaction with the new e-course quality. From Fig 6, it can be seen that $24.10 \%$ strongly agreed and $61.65 \%$ agreed that the course guide and description were clear in the new developed ecourse. However, only 5.79\% disagree and 5.0\% strongly disagree with $3.44 \%$ students being neutral. Analysis concluded that students are satisfied with the e-course description in the new Blackboard Learn LMS based on full online courses.

Table 3. Students questionnairer and feedback regarding handling e-course and technical support

\begin{tabular}{|l|c|c|c|c|}
\hline \multicolumn{1}{|c|}{ Questions } & \multicolumn{2}{c|}{ Yes } & \multicolumn{2}{c|}{ No } \\
\cline { 2 - 5 } & $\boldsymbol{T}$ & $\boldsymbol{\%}$ & $\boldsymbol{F}$ & $\boldsymbol{\%}$ \\
\hline I received training on how to handle full e-courses & 329 & 51.48 & 310 & 48.51 \\
\hline I can deal with Blackboard Learn through the computer & 494 & 77.30 & 145 & 22.69 \\
\hline I can deal with Blackboard Learn through smart devices & 557 & 87.16 & 32 & 12.83 \\
\hline $\begin{array}{l}\text { Full e-course teachers have enough experience to solve any problems encountered } \\
\text { while studying the course }\end{array}$ & 450 & 70.42 & 189 & 29.57 \\
\hline $\begin{array}{l}\text { I know of ways and mechanisms to benefit from technical support for the } \\
\text { Deanship of e-learning }\end{array}$ & 306 & 47.88 & 333 & 52.11 \\
\hline Responds promptly when requesting technical support & 323 & 50.54 & 316 & 49.49 \\
\hline
\end{tabular}




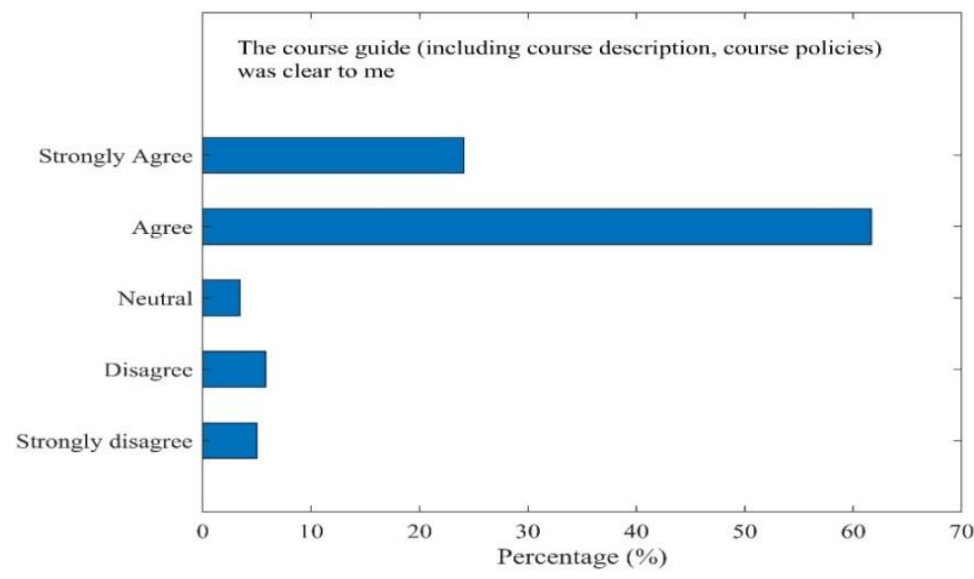

Fig. 6. Students feedback about course guideline

From Fig 7, it can be seen that $29.73 \%$ strongly agreed and $40.37 \%$ agreed that faculty members were enthusiastic about using e-courses. However only $5.63 \%$ disagreed and $6.57 \%$ strongly disagreed with $17.68 \%$ of students being neutral. In comparing both agree and disagree feedbacks from the students, it is concluded that in the new Blackboard Learn LMS students were more enthusiastic about using electronic courses.

Fig 8 shows that $26.44 \%$ strongly agreed and $42.41 \%$ agreed that browsing the course and related information with e-courses in the newly developed Blackboard Learn LMS were easy. Only $7.66 \%$ disagreed and $7.35 \%$ strongly disagreed whereas $16.11 \%$ students were neutral. Detailed comparison of the students agree and disagree feedback reveals that it was easy to browse courses and related details in the e-course based on the Blackboard Learn LMS.

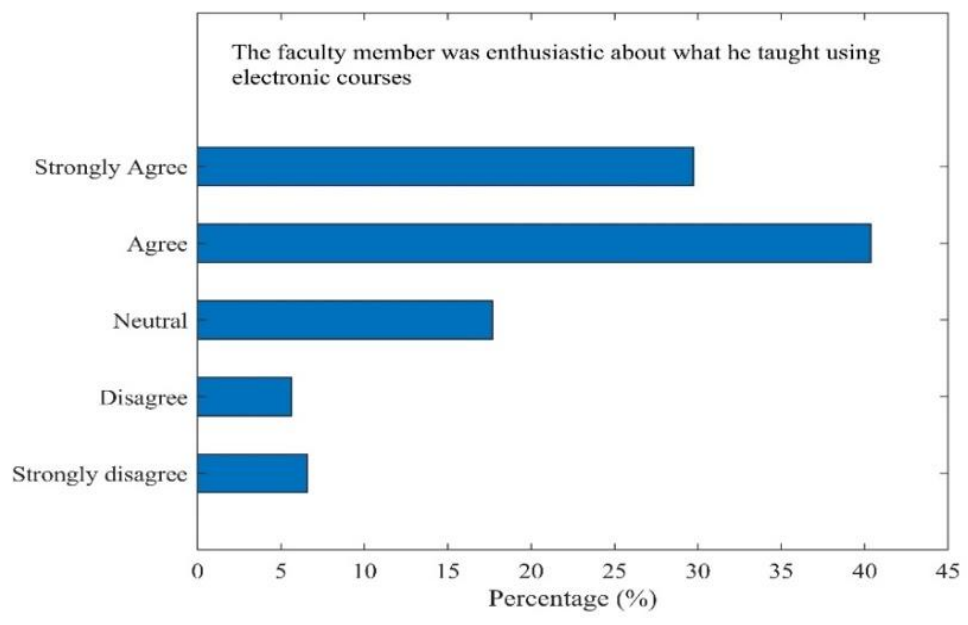

Fig. 7. Faculty involvement in new e-course 


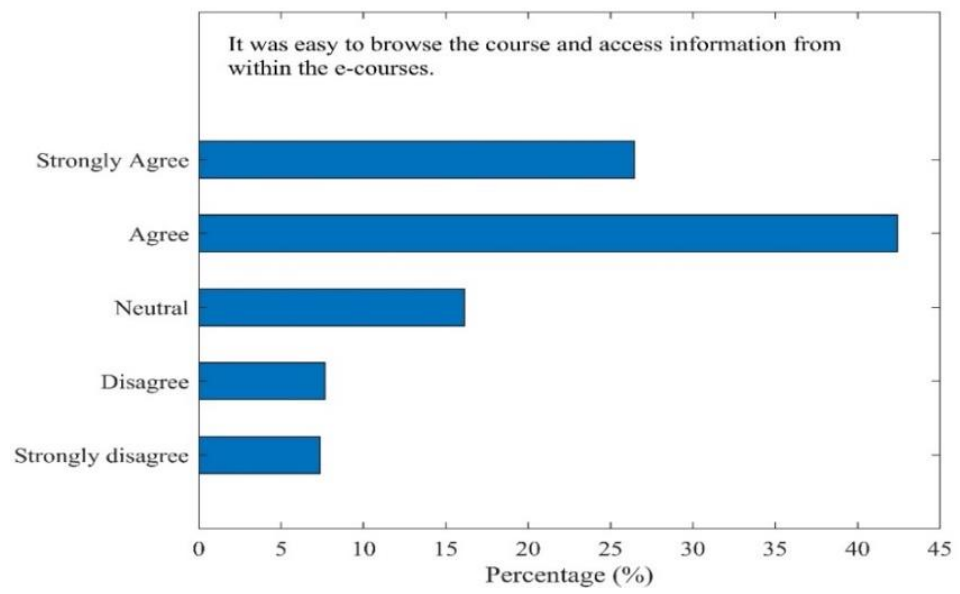

Fig. 8. Data accessibility with respect to student point of view

Fig 9 shows that $22.53 \%$ strongly agreed and $35.21 \%$ agreed that the e-course helped them improve their teamwork skills, whereas $12.98 \%$ disagreed and $10.95 \%$ strongly disagreed that it doesn't help to improve teamwork, while the remaining $18.30 \%$ of students were neutral. This analysis concludes that the majority of the students agreed that the newly developed e-course helps them improve teamwork.

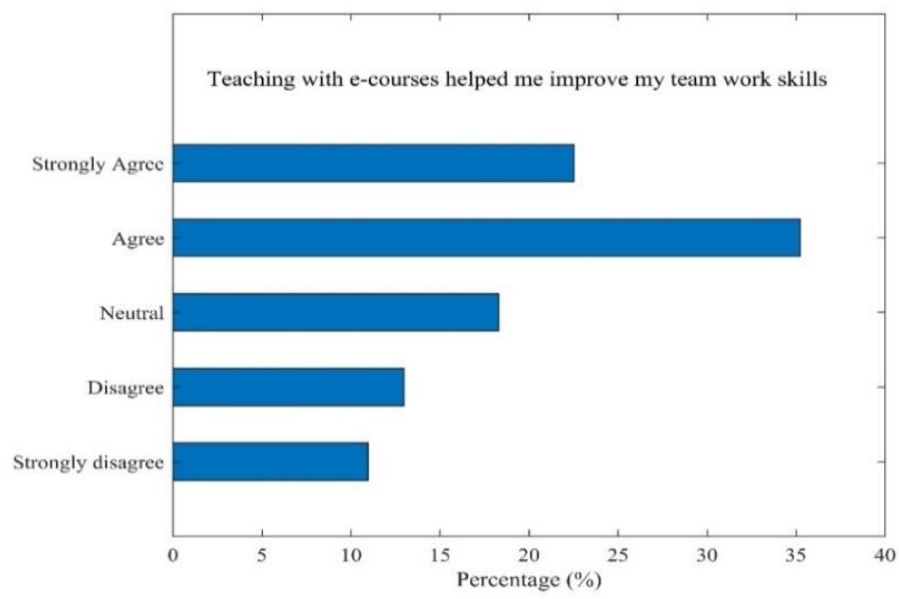

Fig. 9. Development of teamwork skill in e-course

Finally, Fig 10 shows that $29.42 \%$ strongly agreed and $36.93 \%$ students agreed that the new e-course based on full online course of Blackboard Learn LMS is high quality and as per their expectation, however only $6.72 \%$ disagree and $9.70 \%$ strongly disagree to this decision from the university, while $17.21 \%$ of students were neutral. 


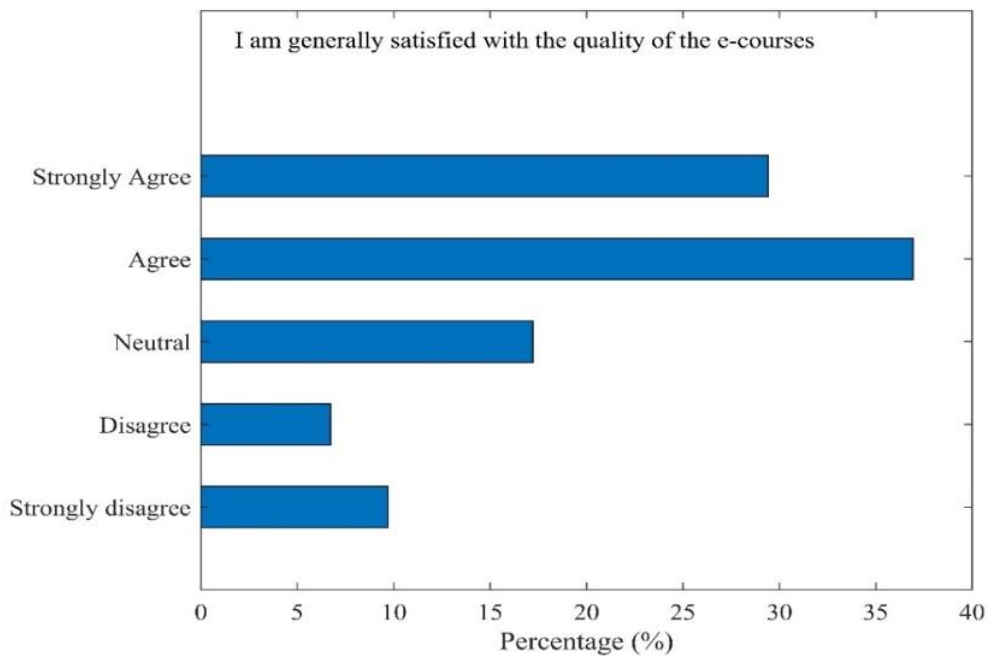

Fig. 10.Quality of the e-course

Table 4. Quantitative evaluation of the student's feedbacks

\begin{tabular}{|l|c|c|c|c|c|}
\hline \multicolumn{1}{|c|}{ Questions } & \multicolumn{5}{|c|}{ Faculty decision (\%) } \\
\cline { 2 - 7 } & $\begin{array}{l}\text { Strongly } \\
\text { disagree }\end{array}$ & Disagree & Neutral & Agree & $\begin{array}{l}\text { Strongly } \\
\text { agree }\end{array}$ \\
\hline $\begin{array}{l}\text { The course guide (including course description, course } \\
\text { policies) was clear to me }\end{array}$ & 5.0 & 5.79 & 3.44 & 61.65 & 24.10 \\
\hline $\begin{array}{l}\text { The faculty member was enthusiastic about what he taught } \\
\text { using electronic courses }\end{array}$ & 6.57 & 5.63 & 17.68 & 40.37 & 29.73 \\
\hline $\begin{array}{l}\text { It was easy to browse the course and access information } \\
\text { from within the e-courses }\end{array}$ & 7.35 & 7.66 & 16.11 & 42.41 & 26.44 \\
\hline $\begin{array}{l}\text { Teaching with e-courses helped me improve my teamwork } \\
\text { skills. }\end{array}$ & 10.95 & 12.98 & 18.30 & 35.21 & 22.53 \\
\hline I am generally satisfied with the quality of the e-courses. & 9.70 & 6.72 & 17.21 & 36.93 & 29.42 \\
\hline
\end{tabular}

\section{Discussion}

With the advance in the e-learning course system based on Blackboard Learn, a number of systems have been implemented and scanned for use in the educational institutions. As per the discussion in the literature review, numerous authors studied the implemented systems through survey-based analysis. Here, is this paper, the author carried out a detailed investigation of the new developed full online course system at the western branch colleges of Qassim University in the Kingdom of SaudiArabia.

In this analysis, the survey was done for both students and teachers for new online courses.

Both students and teachers were processed through the survey for the new online LMS courses. Based on feedback from faculty members and students, analysis reveals 
that besides some challenges and limitations, about $65.23 \%$ of the faculty members think that the objective of the course can be achieved, and $26.08 \%$ agree that the econtent of the course is characterized by language integrity and clarity. Furthermore, $73.9 \%$ of the faculty members received training and can handle the full e-course. A similar study conducted by Hanan Ahmed Alzawaidy concluded that about $67 \%$ of faculty members faced no obstacles [24].

About $91.3 \%$ of the faculty members are experts in the self-learning management process. A detailed analysis shows that faculty members are reliable with the use of ecourses for thoroughly guiding the students regarding practical activities of the course. However, the course professor thinks that students fail to present practical activities to their course tutor.

Moreover, a comprehensive overview of student's feedback leads to the conclusion that despite $61.54 \%$ of students receiving training for handling the full e-course, the highest ratio of students can deal with the Blackboard Learn system, not only through a computer but also with smart devices. A study by Hossain MM suggested that firsttime Blackboard Learn users are most likely to overall be satisfied at using it without any significant difference between males and females [25].

About $85.75 \%$ of students agree that the course guide and description were clear, $68.85 \%$ of students can easily access e-course content and a total of $66.35 \%$ are satisfied with the new e-course. Studies conducted by Ana Carvalho concluded that the online courses were on a par with the real classroom lessons and had a similar impact on the learning process [26]. However, this system lacks solving technical issues and the technical support team also don't reply promptly. But it is good that ecourse teachers have enough experience and can help students in the case of an emergency.

\section{Conclusion}

In this paper, the author evaluates the Blackboard Learn Learning Management System through a survey for the faculty members and students in the western branch colleges of Qassim University in the Kingdom of Saudi Arabia on full online courses developed for e-learning in the academic year of 2016. The main objective of the survey was around difficulties and limitations which faculty membersand students face. A comprehensive evaluation of the system based on faculty members and students feedback reveals that overall, the system meets the criteria to achieve the course objectives, the course content is characterized with scientific accuracy and the students are satisfied. However, the developed e-course still required significant work for improvements in the future.

A detailed investigation including difficulties and limitations in the full online ecourse system reveals that the full online e-course is as a result of advancement in the field of LMS. However, despite the many advantages, it has some shortcomings to be sorted out in the near future. Both faculty members and students feel confident in the use of the new developed e-course content. However, faculty members are thought to intend to improve the system for student's skill development, whereas students are 
worried about the solution to technical issues. Furthermore, authors recommend the technical team to provide a prompt response to make the system more reliable. The aforesaid shortcoming is recommended for improvement in the near future in the updated version of the system.

\section{Acknowledgement}

The authors are thankful to Dr. Ahmed Mohammed Abdelmotaleb Director of the e-learning unit in the College of Arts and Science, Arras for his support and precious guidance regarding data collection and analysis in the western branch colleges of Qassim University.

\section{References}

[1] Poon, J. (2013). Blended Learning: An Institutional Approach for Enhancing Students' Learning Experiences. Merlot Journal of Online Learning and Teaching, 9(2), 271-288.

[2] Govender, I., \& Mkhize, M. (2015). e-learning in Place of Face-to-face Lectures: An Exploratory Study of Students' Perceptions. Alternation, 22(1), 183-203.

[3] Heirdsfield, A. (2011). Blackboard as an online learning environment: What do teacher education students and staff think? Australian Journal of Teacher Education, 36(7), 1-16. https://doi.org/10.14221/ajte.2011v36n7.4

[4] Sang, Y.-T., Chang, K.-E., \& Liu, T.-C. (2016). The effects of integrating mobile devices with teaching and learning on students' learning performance: A meta-analysis and research synthesis. Computers \& Education, 94, 252- 275. https://doi.org/10.1016/i.com pedu.2015.11.008

[5] Peter Bradford et al. The Blackboard learning system: The Be All and End All in Educational Instruction? J. Educational Technology Systems, Vol. 35(3) 301-314, 2006. https://doi.org/10.2190/x137-x731-5261-5656

[6] Devraj M, Irene G. Use of the Blackboard learning management system. EURASIA J Math Sci and Tech Ed,2018, 14(7):3069-3082

[7] Machado M, Tao E. Blackboard vs. Moodle: Comparing user experience of learning management systems. November 2007, Proceedings - Frontiers In Education Conference. https://doi.org/10.1109/fie.2007.4417910

[8] N. Umunnakwe and Q. Sello, "Effective utilization of ICT in English language learning The case of University of Botswana undergraduates," Universal Journal of Educational Research, vol. 4, no. 6, pp. 1340-1350, 2016. https://doi.org/10.13189/ujer.2016.040611

[9] U. T. Alturki, A. Aldraiweesh, and Kinshuck, "Evaluating the usability and accessibility of LMS "blackboard" at King Saud University," Contemporary Issues in Education Research, vol. 9, no. 1, pp.33-44, First Quarter 2016. https://doi.org/10.19030/cier.v9i1.9548

[10] Mohammad H. H. El-ghamry, "The effect of blackboard collaborate-based instruction on pre-service teachers' achievement in the EFL teaching methods course at faculties of education for girls," English Language Teaching, vol. 9, no. 3, pp. 49-67, February 2016. https://doi.org/10.5539/elt.v9n3p49

[11] Jayson S (May 2006) Blackboard breaks through. The Motley Fool. www.fool.com/News/ $\underline{\mathrm{mft} / 2006}$ 
[12] Pittinsky M, Bell T (2005) From the dining hall to the campus bookstore to a networked transaction environment: Overview white paper. Blackboard, Inc.

[13] Pittinsky M (2004) The networked learning environment: Overview white paper. Blackboard, Inc.

[14] Mioduser, D., Nachmias, R., Oren, A. and Lahav, O. (1999) Web-Based Learning Environments: Current States and Emerging Trends. In: Collis, B. and Oliver, R., Eds., EdMedia 1999: World Conference on Educational Multimedia, Hypermedia and Telecommunications, Association for the Advancement of Computers in Education, Seattle, WA, 753-758. https://doi.org/10.1006/jnca.1999.0093

[15] Mioduser, D., Nachmias, R., Oren, A. and Lahav, O. (1999) Web-Based Learning Environments (WBLE): Current Implementations and Evolving Trends. Journal of Network and Computer Applications, 22, 233-247. https://doi.org/10.1006/jnca.1999.0093

[16] Moeller, B. and Reitzes, T. (2011) Integrating Technology with Student-Centered Learning. Education Development Center, Inc. (EDC), Quincy, MA. Nellie Mae Education Foundation.

[17] Bradford, P., Porciello, M., Balkon, N. and Backus, D. (2006-2007) The Blackboard Learning System: The Be All and End All in Educational Instruction? Journal of Educational Technology Systems, 35, 301-314. https://doi.org/10.2190/x137-x731-5261$\underline{5656}$

[18] Carvendale, D. (2003) Study of Wisconsin Professors Finds Drawbacks to CourseManagement Systems. Chronicle of Higher Education, 49, A26.

[19] Anderson, J.W. (2003) Faculty Perspectives of the Blackboard Course Delivery System.

[20] Lee, Y. and Choi, Y. (2011) A Review of Online Course Dropout Research: Implications for Practice and Future Research. Educational Technology Research and Development, 59, 593-618. https://doi.org/10.1007/s11423-010-9177-y

[21] Davis, E.A., Hodgson, Y. and Macaualy, J.O. (2012) Engagement of Students with Lectures in Biochemistry and Pharmacology. Biochemistry and Molecular Biology Education, 40, 300-309. https://doi.org/10.1002/bmb.20627

[22] Leeds, E., Campbell, S., Baker, H., Radwan, A., Brawley, D. and Crisp, J. (2013) The Impact of Student Retention Strategies: An Empirical Study. International Journal of Management in Education, 7, 22-43. https://doi.org/10.1504/ijmie.2013.050812

[23] Alzahrani, M.M. and Aljraiwi, S.S. (2017) Effectiveness of Using Blackboard Collaborate Tools in Promoting Practical Skills among Students of the Foundation Year in e-Learning Course. British Journal of Education, 5, 19-53.

[24] H. A. Zaki and H. El Zawaidy, "Using BLACKBOARD in online learning at Saudi universites: faculty members's perceptions and existing obstacles," The International Journal of Interdisciplinary Educational Studies, vol. 3, no. 7, 2014. https://doi.org/10.128 $\underline{16 / 0006902}$

[25] Hossain, M. M., Akhtar, S., \& Rahman, M. A. (2017). A study to evaluate users' satisfaction of Blackboard Learn. People: International Journal of Social Sciences, 3(1).

[26] Ana Carvalho June 2010 British Journal of Educational Technology 42(5):824 - 841

[27] Liu, H. (2016). An analysis on blended learning pattern based on blackboard network platform: A case study on the course of recruitment and employment management. International Journal of Emerging Technologies in Learning (iJET), 11(09), 4-8. https://doi.org/10.3991/ijet.v11i09.6124

[28] Xu, J. L., Liu, X. J., Wang, H. X., Zhang, J. Q., Liu, Y. Y., \& Zhang, T. (2014). The Practice and the Reflection of Network-Assistance Teaching based on the Platform of Blackboard. International Journal of Emerging Technologies in Learning (iJET), 9(8), 4244. https://doi.org/10.3991/ijet.v9i8.3635 
[29] Kasim, N. N. M., \& Khalid, F. (2016). Choosing the Right Learning Management System (LMS) for the Higher Education Institution Context: A Systematic Review. International Journal of Emerging Technologies in Learning, 11(6). https://doi.org/10.3991/ijet.v11i06. $\underline{5644}$

\section{Author}

Fahad Alturise is currently working as an Assistant Professor in the computer department, College of Science and Arts in Ar Rass, Qassim University, Saudi Arabia. He has an experience of twelve years in the field of teaching and research. He holds an $\mathrm{PhD}$ in Information Technology from Flinders University. His primary research interests include e-learning, e-services, e-government, IOT, ICT adaption and software engineering. He has published six papers in international journals/conference proceedings $\mathrm{He}$ was a member of the Australian Computer Society (ACS) for four years.

Article submitted 2020-03-12. Resubmitted 2020-04-26. Final acceptance 2020-04-27. Final version published as submitted by the authors. 